E3 Journal of Business Management and Economics Vol. 11(1). pp. 021-026 February, 2021

Available online http://www.e3journals.org

ISSN 2141-7482 (C) E3 Journals 2021

DOI: http://dx.doi.org/10.18685/EJBME(11)1_EJBME-20-014

Full Length Research Paper

\title{
E-marketing and the hotel business promotion: Prospect and challenges in selected hotels in Ado-Ekiti, Nigeria
}

\author{
Aina Olayinka Christopher, $\mathrm{PhD}$ \\ Department of Tourism and Events Management Afe Babalola University, Ado Ekiti, Nigeria \\ Email: christopheraina01@gmail.com
}

Accepted 10 December, 2020

This research study was designed to critically examine the prospects and challenges of e-marketing in the hotel business promotion. The study intensively revealed the challenges of e-marketing in hotel business and proffered solutions to it. This research was conducted using all the four hotel business (Prosperous Royal Hotel and Resort, Queen's Court Hotel, Pathfinder Hotel and Holiday Inn, Koltotel Plaza \& Suit) within Ado-Ekiti, Nigeria. Analysis of data collected through questionnaires was carried out using inferential statistics of percentage and frequency in determining the significance of hypotheses formulated. The result of the hypotheses shows that there is significant need for the adoption of e-marketing in the hotel business because it has been a subject in the creation of awareness and advertising of its products around the world, it also revealed the fact that e-marketing organizational challenges is to gain agreement with hotel managements regarding how to proceed with operations, innovations and exploration in the business which needs to be resolved based on the opportunities and success ahead. It was concluded that e-marketing is an essential tools in the hotel business promotion for development. It was recommended based on the findings that to gain competitive advantage in the demanding hotel business, e-marketing must be the forerunner, it also notes that it is important nowadays for any of these industries to have its own website, promote its products through social networks.

Keywords: E-marketing, Hotel Business, Promotion, Prospect and Challenge

\section{INTRODUCTION}

The recent growth of the Internet has considerably changed the operating environment of the hotel industry. The Internet has become an innovative marketing tool in offering travel information and online transactions (Doolin, Burgess, \& Cooper, 2002). The informationbased nature of tourism products means that the Internet, which offers global reach and multimedia capability, is an increasingly important means of promoting hotel business services.
Today, internet has become a global village where everyone visit often to get informed about things that interest them, a websites that is well-designed and easy to navigate provide independent hotels with an inexpensive and effective platform for marketing and advertising, which potentially increase their competitiveness in the marketplace (Lituchy\& Rail, 2000; Merono-Cerdan\& Soto-Acosta, 2007).The website marketing can potentially provide distinct value to the 
hotels. These come from the offering of information online, the possibility of establishing communications and exchange of information and the conducting of transactions online. The rapid adoption of Internet marketing by hotels has yielded myriad (Hashim, Murphy, Purchase, \& O'Connor, 2010; Scaglione, Schegg, \& Murphy, 2009).It is apparent in the Nigeria economy that the introduction of the internet has reformed the structure and level of productivity of different sectors of the economy such as in the hospitality, travel, hotels and tourism sectors etc. The operation of the internet has altered the rules of doing business significantly. Therefore marketing firms have no alternative than to adhere to it. The Internet plays a significant role in all elements of the marketing mix and the communication process of interface between a business and its customers" Perks (2004).

\section{Literature review}

Studies focusing on the Internet have been conducted, particularly as it relates to advertising and marketing (Wan 2002). According to recent studies, the Internet is the most effective when used as an advertising and marketing tool (Cai et al., 2004; Garces et al., 2004; Law and Hsu, 2005; Lee et al., 2006; Bui et al., 2006; Buhalis and Law, 2008). Poel and Leunis (1999) believe that the Internet is an important channel of distribution for consumers.

The Internet provides opportunities for an organization to enhance its" business in a cost-effective and practical manner. That is, the Internet can be used to conduct marketing research, reach new markets, better serve customers, distribute products faster, solve customer problems, and communicate more efficiently with business partners. With the development of the Internet increasing dramatically in recent years, the hospitality and tourism industry has begun to use Internet as part of their marketing effort (Wan, 2002). At the present day, an increasing number of lodging customers make reservations directly with hotels by bypassing traditional distribution channels (Jeong et al., 2013). The importance of Internet applications in the hotel business has been emphasized by academic researchers and industry practitioners. To hotel practitioners, the Internet offers a means for them to sell their products to global customers without any geographical or time constrains (Law and Hsu, 2015) through the use of E-marketing.In

the existing hospitality literature, prior studies have been conducted to measure how information through hotel websites is. These studies have also tried to classify the website features (Zafiropoulos and Vrana, 2016). A study conducted by Murphy, Forrest, Wotring and Brymer (2016), recorded thirty-two different services and placed them into four nonexclusive categories: promotion and marketing, service and information, interactivity, and technology and management. They claimed that cyber hoteliers should continuously analyze how these features effect or enhance the mission, margin, mechanics, marketing and maintenance of their websites

In Buhalis's study (2010), it was found that information technologies, especially the Internet, can be used as an effective business tool in the hotel industry to promote their hotel business and enhance their profitability. Although the website can be viewed as the basis for emarketing activities in hotels (Andrlić, 2007), there are several e-marketing tools that can be adopted by the hotel industry. El-Gohary (2012) states that small tourism organizations in Egypt use five basic e-marketing tools such as Internet marketing, e-mail marketing, mobile marketing, intranet marketing and extranet marketing, as well as different e-marketing forms - Business to Business Marketing (B2B), Business to Consumer Marketing (B2C) and Business to Government Marketing (B2G). Companies have changed their traditional business strategies into online marketing and have become full-fledged service providers with the facility to offer a full range of e-commerce products to suit customer needs and taste at any time. E-marketing is cost effective and measurable compared to all other marketing strategies. It benefits both customers and marketers simultaneously. Customers can shop products 24 hours a day from anywhere in the world and interact with sellers (via seller's website) to find the product or service information they desire. Hotel can interact with customers and enable them to learn more about customers' needs, build good customer relationships, increase efficiency and reduce costs, and gain access to national and international markets quickly. In below figure, main categories of digital media communications channels are classified:With proper E-marketing means through perfect web design, hotels business will yield maximum profitability and increase their services globally. Thus, for the purpose of this research, the research question includes the following:

- There is significant relationship between Emarketing and Hotel business promotion?

- E-marketing limits the achievement of hotel business?

- E-marketing is an avenue at which hotel business product and service are been market? 


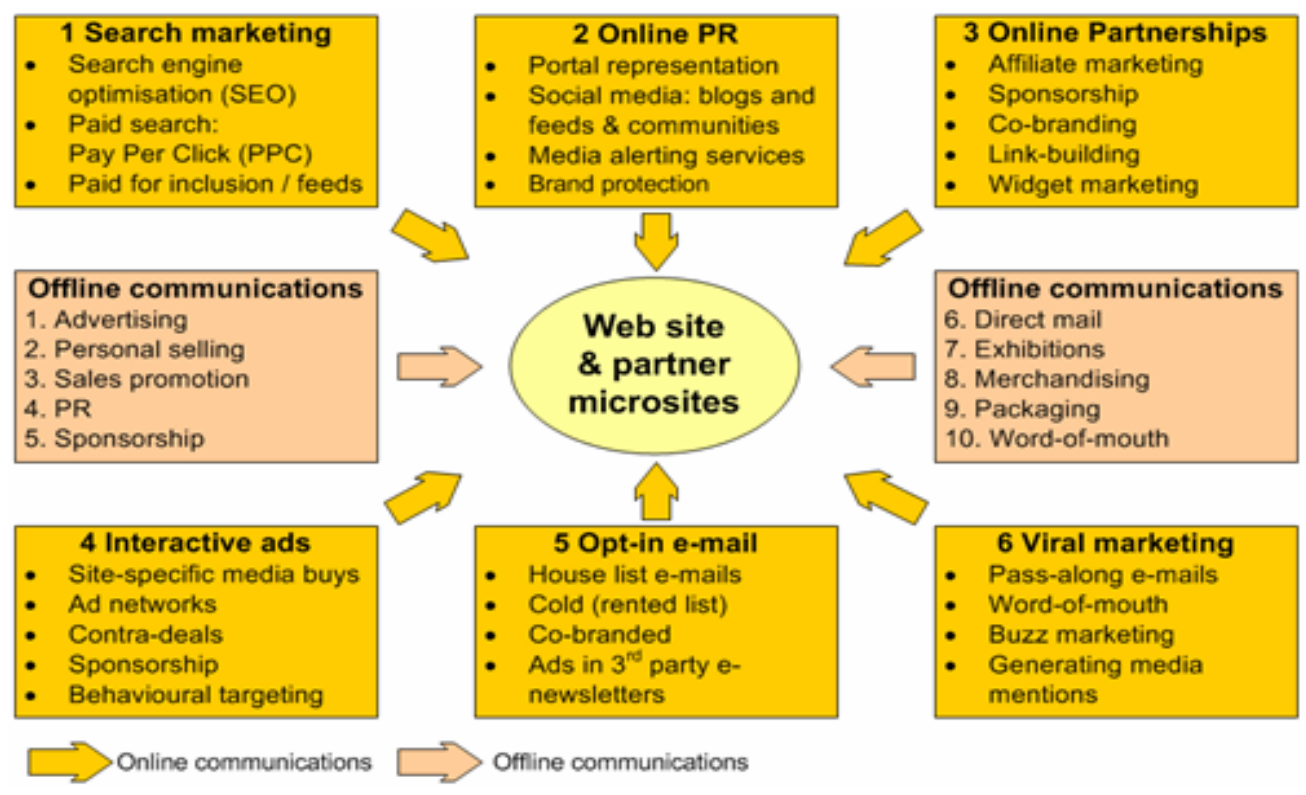

Figure 1. Categories of e-communications tools for media channels (Source: Chaffey and Smith, 2008) Electronic copy available at: https://ssrn.com/abstract=2955951

\section{The hypothesis for the study includes:}

$\mathrm{H}: 1$ There is no significant relationship between emarketing and hotel business promotion.

$\mathrm{H}: 2$ E-marketing does not limit the achievement of hotel business.

$\mathrm{H}: 3 \mathrm{E}$-marketing is not an avenue at which hotel business product and service are been market

\section{Material and Methods}

Thus, 150 questionnaires were administered to Hotel management. A total of one hundred and thirty (130) questionnaires were returned, representing $86.7 \%$. Inferential statistics of percentage and frequency are used to analyze data collected. Findings were discussed as well as implications to hotel businesses are highlighted.

\section{Study Area}

For the purpose of this research work, four hotels industry within Ado-Ekiti in Ekiti State where selected and questionnaires were administered to them. These hotels are:Prosperous Royal Hotel and Resort
Queen's Court HotelPathfinder Hotel and Holiday Inn Koltotel Plaza \& Suit

\section{Data collection}

The study adopted an observational rapid field survey procedure as recommended by Malgosiaet al., (2013) which included combining data from survey, documentation, and information from key players, interviews and questionnaire. The questionnaires were centered on three main areas - E-marketing, Hotel business promotion, and prospect and challenge. 150 questionnaires were administered to the hotel management which cut across Housekeeper, Accountants, marketing officer and ICT officer. The study conducted Cronbach Alpha which found to be 0.601 that is $60 \%$ of the appropriateness of the questions

\section{Results and Discussion}

Table 1 provides statistical information with regards to the respondents Sex, Age, Marital Status, Educational Qualification and Years of Experience at their various hotels within the study area in Ado-Ekiti. Table 1 show that $63.8 \%$ of the respondents were male while $36.2 \%$ of 
Table 1. Respondents Sex, Age, Marital status, Educational Qualification and years of working Experience

\begin{tabular}{|c|c|c|c|}
\hline $\mathrm{S} / \mathrm{N}$ & Purpose Classification & Frequency & Percent (100\%) \\
\hline \multirow[t]{4}{*}{1.} & Respondents Sex & & \\
\hline & male & 83 & 63.8 \\
\hline & female & 47 & 36.2 \\
\hline & Total & 130 & $100 \%$ \\
\hline \multirow[t]{5}{*}{2.} & Respondents age-Group & & \\
\hline & $20-25$ & 64 & 49.2 \\
\hline & $26-30$ & 43 & 33.1 \\
\hline & 31 and above & 23 & 17.7 \\
\hline & Total & 130 & $100 \%$ \\
\hline \multirow[t]{4}{*}{3.} & Respondents Marital Status & & \\
\hline & Single & 98 & 75.4 \\
\hline & Married & 32 & 24.6 \\
\hline & Total & 130 & $100 \%$ \\
\hline \multirow[t]{5}{*}{4.} & Respondents Educational Qualification & & \\
\hline & NCE & 63 & 48.5 \\
\hline & HND/OND & 45 & 34.6 \\
\hline & B.Sc/B.ED & 22 & 16.9 \\
\hline & Total & 130 & $100 \%$ \\
\hline \multirow[t]{5}{*}{5.} & Respondents Years of Experience & & \\
\hline & $1-5$ & 48 & 36.9 \\
\hline & $6-10$ & 69 & 53.1 \\
\hline & 11 above & 13 & 10.0 \\
\hline & Total & 130 & $100 \%$ \\
\hline
\end{tabular}

Source: Field Survey 2020

the respondents were females. It also shows the age of respondents that were administered with questionnaire, $49.2 \%$ of the respondents fell between ages 20-25, $33.1 \%$ of the respondents fell between age 26-30 while $17.7 \%$ fell between 31 and above. This implies that majority of people working in the hotel business are mostly youth which can be deduce as a result of young graduate seeking employment. The marital status showed that $75.4 \%$ of the respondents were single while $24.6 \%$ of the respondents were married. This can be seen as a result of most hotel worker is youth. The educational qualification showed that $48.5 \%$ of the respondents hold N.C.E, $34.6 \%$ of the respondents hold HND/OND while $16.9 \%$ of the respondents hold B.Sc/B.ED. It also showed that $36.9 \%$ of the respondent fell between 1-5years, $53.1 \%$ fell between 6-10years while $10 \%$ fell between 11 and above years of experience.

The study carried further analysis on the hotel management views with regards to their opinion on how E-marketing can lead to Hotel business promotion. Table
2 provides these details. Table 2 reveals that there is significant relationship between E-marketing and Hotel business promotion with $48.5 \%$ respondents agreeing to that while 12.3 respondents do not think so. This means that with the invention of E-marketing, hotel business have attain a new high in their business. The import of this result is that the management of the hotels should consider having their own web site and advertising their hotels to the general customer to create more awareness about their product and services. The table also reveals that E-marketing limits the achievement of hotel business, with $45.4 \%$ of respondents disagreeing with this while only $6.9 \%$ agreeing. This implies that Emarketing does not limits the achievement of hotel business, hence hotel management are strongly advice to adopt the use of E-marketing to promote their business through global awareness creation.More so, the study result reveals that E-marketing is an avenue at which hotel business product and service are been market with $30.0 \%$ of the respondents agreeing to this while $20.8 \%$ disagreeing with this view point. This could be attributed 
Table 2. Relationship between E-marketing and Hotel business promotion

\begin{tabular}{lccccc}
\hline Items & $\begin{array}{c}\text { Strongly } \\
\text { Disagree }\end{array}$ & Disagree & Undecided & $\begin{array}{c}\text { Agree } \\
\text { Strongly } \\
\text { Agree }\end{array}$ \\
\hline There is significant relationship between E- & 3 & 16 & 5 & 63 & 43 \\
marketing and Hotel business promotion & $(2.3 \%)$ & $(12.3 \%)$ & $(3.8 \%)$ & $(48.5 \%)$ & $(33.1 \%)$ \\
E-marketing limits the achievement of hotel & 44 & 59 & 7 & 9 & 11 \\
business & $(33.8 \%)$ & $(45.4 \%)$ & $(5.4 \%)$ & $(6.9 \%)$ & $(8.5 \%)$ \\
E-marketing is an avenue at which hotel business & 22 & 27 & 11 & 39 & 31 \\
product and service are been market & $(16.9 \%)$ & $(20.8 \%)$ & $(8.5 \%)$ & $(30.0 \%)$ & $(23.8 \%)$ \\
E-marketing does not meet the organizational & 32 & 49 & 13 & 19 & 17 \\
goal of hotel industry. & $(24.6 \%)$ & $(37.7 \%)$ & $(10.0 \%)$ & $(14.6 \%)$ & $(13.1 \%)$ \\
The setup of E-marketing is a challenge to the & 47 & 58 & 2 & 11 & 12 \\
development of hotel industry. & $(36.2 \%)$ & $(44.6 \%)$ & $(1.5 \%)$ & $(8.5 \%)$ & $(9.2 \%)$ \\
The rate at which E-marketing develop & 16 & 21 & 5 & 62 & 26 \\
encourages the hotel management & $(12.3 \%)$ & $(16.2 \%)$ & $(3.8 \%)$ & $(47.7 \%)$ & $(20.0 \%)$ \\
E-marketing is a channel at which hotel industry & 7 & 10 & 0 & 41 & 72 \\
has been known nationwide & $(5.4 \%)$ & $(7.7 \%)$ & & $(31.5 \%)$ & $(55.4 \%)$ \\
\hline
\end{tabular}

Source: field survey 2020

to the fact most hotels in Ado-Ekiti environs and Nigeria as a whole now make use of website to advertise their product and service. The result further reveal that hotels management is now motivated to make use of emarketing channels as an avenue to market their services with the combine of respondent who strongly agree and agree tally $53.8 \%$. The result also reveals that "E-marketing does not meet the organizational goal of hotel industry" is said to be false as $33.7 \%$ of respondents disagreeing with the view. In addition, $62.3 \%$ of the hotel management agreed and strongly agree that their expectation were met through the use of $e$ marketing and they were satisfied with the services provided by the e-marketing platform. It can be conclude that the hypothesis which stated that Emarketing does not limits the achievement of hotel business is found to be true and accepted based on the fact that the majority of these hotel management $(45.4 .0 \%)$ disagree that e-marketing limit their achievement. Also the hypothesis which states that Emarketing does not meet the organizational goal of hotel industry is found not to be true and accepted which is in line with view point of the management, $62.3 \%$ of their organization goals were met through the use of emarketing channels. Furthermore, the hypothesis which states E-marketing is not an avenue at which hotel business product and service are been market is found not to be true and thus rejected which is consonance with hotel management that strongly disagree with the view and agree/strongly agree that e-marketing is an avenue at which hotels business market their product and services at $53.8 \%$; this is as a result of the significance of Information Communication Technology in creating awareness to the world through the uses of E-marketing .

\section{Conclusion and Recommendation}

From this research work, it can be concluded that Emarketing is an essential tool in the hotel business for development.Wider prospect reach - the internet has become part of everyone's life. So for whatever products you offer, there is already an existing market on the World Wide Web. With e-marketing, it allows you to find new markets and potentially compete worldwide with only a small investment. 24/7 marketing - with a website your customers can find out about your products and make purchases even if your physical (bricks \& mortar) premises are closed or you don't have physical premises at all. The following recommendations were offered based on the findings of the study:To gain competitive advantage in the demand for hotel market, it is important nowadays for the industry to have its own website, promote its products through social networks and mobile applications, use e-mail as a channel of communication with its business partners and customers, and apply all available information-communication technology (ICT). It needs to provide all information for potential clients in one place at any time of day, from anywhere in the world. That can be possible by using innovative ways of 
communication and by adapting business operations to demanding requirements of the modern tourist market. This imposes the innovation of practices and the implementation of new technologies in business processes. Therefore, there is a need for awareness about the necessity of applying ICT in the hotel business.

\section{Reference}

Andrlić B et al. (2010) "Effect of e-marketing on consumer behavior in hospitality", Tourism. Hospitality. Management, Conference Proceedings, p. 692-706

Buhalis D et al. (2008). "Progress in Information Technology and Tourism Management: 20 Years on and 10 Years after the Internet the State of e Tourism Research. Tour.Manage. 29: 609-623.

Cai L. et al (2004). "Content Delivery Performance of World Wide Web Sites of US Tour Operators Focusing on Destinations in China". Tour. Manage. 25: 219-227.

El-Gohary H (2012) "Factors affecting E-Marketing adoption and implementation in tourism firms: An empirical investigation of Egyptian small tourism organizations", Tour. Manage. 33(5): 12561269.

Jeong M, Oh H, Gregoire M (2003).Conceptualizing Web Site Quality and its Consequences in the Lodging Industry. Hosp. Manage. 22: 161-175.
Law R et al. (2015). "Customers Perceptions on the Importance of Hotel Web Site Dimensions and Attributes" Int. J. Contemp. Hosp. Manage. 17 (6): 493-503.

Murphy $J$ et al. (2016). "Hotel Management and Marketing on the Internet. Cornell Hotel Restaurant Adm". Q., 37 (3): 70-82.

Wan CS (2002). The Web Sites of International Tourist Hotels and Tour Wholesalers in Taiwan.Tour.Manage., 23: 155-160.

Zafiropoulos C et al. (2016). "A Framework for the Evaluation of Hotel Websites": the Case of Greece. Inform. Technol. Tour., 8: 239-254. 